\title{
Dermatoskopija u dijagnostici različitih kliničkih tipova melanoma
}

\section{Dermoscopy in the diagnosis of different clinical types of melanoma}

\author{
Tea Majnarić, Larisa Prpić Massari*
}

\begin{abstract}
Sažetak. Melanom je zloćudni tumor kože i sluznica, izrazito sklon ranom limfogenom i hematogenom metastaziranju. Incidencija melanoma povećava se u cijelom svijetu, stoga je melanom sve značajniji javnozdravstveni problem. Dermatoskopija je neinvazivna dijagnostička metoda koja omogućuje vizualizaciju morfoloških struktura melanocitnih i nemelanocitnih kožnih promjena koje nisu vidljive golim okom te tako povezuje klinički pregled i patohistološku dijagnostiku. $U$ analizi se koristi algoritam u dva koraka kojim se u prvom koraku procjenjuje je li promjena melanocitna ili nemelanocitna na temelju nazočnosti struktura kao što su pigmentna mreža, točke i globuli, homogena pigmentacija, radijalni tračci i paralelni uzorak. Ako je promjena melanocitna, u drugom koraku određujemo radi li se o dobroćudnoj ili zloćudnoj promjeni pomoću brojnih metoda kao što su analiza uzorka, lista sedam točaka, $A B C D$ metoda te Menziesova metoda. Kod većine melanoma, neovisno o metodi koju koristimo, dermatoskopijom uočavamo neke od specifičnih kriterija za ovaj zloćudni tumor, a to su atipična pigmentna mreža, atipične točke i globuli, plavo-bijeli veo, nepravilni tračci, atipični vaskularni uzorak, asimetrična pigmentacija i regresijske strukture. No, pojedini klinički tipovi imaju i svoja specifična obilježja. Stoga, u ovom radu prikazujemo dermatoskopska obilježja vezana uz određeni tip melanoma, što dodatno omogućuje predviđanje patohistološke dijagnoze, prognoze i ishoda bolesti. Razvojem dermatoskopije došlo je do velikog napretka u ranoj dijagnostici melanoma, koja je preduvjet uspješnog liječenja.
\end{abstract}

Ključne riječi: akrolentiginozni melanom; amelanotični melanom; dermatoskopija; lentigo maligni melanom; nodularni melanom; površinsko šireći melanom

\begin{abstract}
Melanoma is a malignant tumor of the skin and mucous membranes, highly prone to early lymphatic or hematogenous metastasis. The incidence of melanoma is increasing significantly worldwide, making melanoma a major public health problem. Dermoscopy is a non-invasive diagnostic method which enables visualization of melanocytic and nonmelanocytic structures that are not visible to the naked eye, thus linking clinical examination and pathohistological diagnostics. In the analysis of pigmented skin lesions, a two-step algorithm is used to first assess whether the lesion is melanocytic or non-melanocytic, based on the presence of typical structures such as pigment network, dots and globules, homogeneous pigmentation, radial streaks, and a parallel pattern. If the lesion is melanocytic, the second step is to determine whether it is a benign or malignant lesion using a number of methods such as pattern analysis, 7-point checklist, ABCD method and the Menzies method. In most melanomas, regardless of the method we use, dermoscopy reveals some of the specific criteria for this malignant tumor, such as atypical pigment network, atypical dots and globules, blue-white veil, irregular streaks, atypical vascular pattern, asymmetric pigmentation and regression structures. However, some clinical types have their own specific characteristics. Therefore, in this paper, we present the dermatoscopic features associated with a specific type of melanoma, which further enables the prediction of pathohistological diagnosis, prognosis, and outcome of the disease. With the development of dermoscopy, great progress has been made in the early diagnosis of melanoma, which is necessary for a successful treatment.
\end{abstract}

Key words: acrolentiginous melanoma; amelanotic melanoma; dermoscopy; lentigo maligna melanoma; nodular melanoma; superficial spreading melanoma
Klinika i katedra za dermatovenerologiju, Klinički bolnički centar Rijeka, Medicinski fakultet Sveučilišta u Rijeci, Rijeka, Hrvatska 


\section{UVOD}

Melanom je zloćudni tumor kože i sluznica koji nastaje iz melanocita. Sklon je ranom limfogenom i hematogenom metastaziranju, stoga je jedan od najopasnijih tumora u čovjeka.

Incidencija, kao i stopa mortaliteta melanoma, u posljednja četiri desetljeća znatno se povećavaju u cijelom svijetu, pa tako i u Hrvatskoj, te melanom postaje sve značajniji javnozdravstveni problem ${ }^{1}$.

Dermatoskopija je neinvazivna in vivo dijagnostička metoda koja omogućuje vizualizaciju morfoloških struktura melanocitnih i nemelanocitnih kožnih promjena koje nisu vidljive golim okom. Razvojem dermatoskopije, koja povezuje kliničku sliku i patohistologiju, došlo je do velikog napretka u ranoj dijagnostici melanoma.

Dermatoskopija je neinvazivna, široko korištena pomoćna dijagnostička metoda koja ima važnu ulogu u kliničkoj i preoperativnoj dijagnostici melanocitnih i nemelanocitnih promjena. Dermatoskop je optički instrument koji omogućuje brzu, in vivo procjenu boja i morfoloških struktura $u$ području epidermisa i papilarnog dermisa koje nisu vidljive golim okom. Glavni dijelovi dermatoskopa su skup leća s povećanjem, ugrađeni sustav za osvjetljavanje sastavljen od halogenih svjetiljki i izvor energije. Osim ručnih standardnih dermatoskopa postoje i digitalni dermatoskopi, a napredni uređaji imaju sustave fotografiranja cijelog tijela $^{2,3}$.

Od metoda koje se tijekom dermatoskopije najčešće koriste su algoritam u dva koraka (engl. two-step algorithm), analiza uzorka (engl. pattern analysis), lista sedam točaka (engl. 7-point checklist) te Menziesova metoda. Algoritam u dva koraka je metoda dermatoskopije, pri čemu se u prvom koraku procjenjuje je li promjena melanocitna ili nemelanocitna. Melanocitnu promjenu prepoznajemo s obzirom na nazočnost najmanje jedne od tipičnih struktura kao što su pigmentna mreža, točke i globuli, homogena pigmentacija, radijalni tračci i paralelni uzorak. Ako je promjena melanocitna, u drugom koraku određujemo radi li se o dobroćudnoj ili zloćudnoj promjeni (slika $1)^{2}$.

Lista sedam točaka boduje nazočnost dermatoskopskih kriterija specifičnih za melanom, a to su atipična pigmentna mreža, plavo-bijeli veo, atipični vaskularni uzorak, atipične točke i globuli, nepravilni tračci, asimetrična pigmentacija i re-

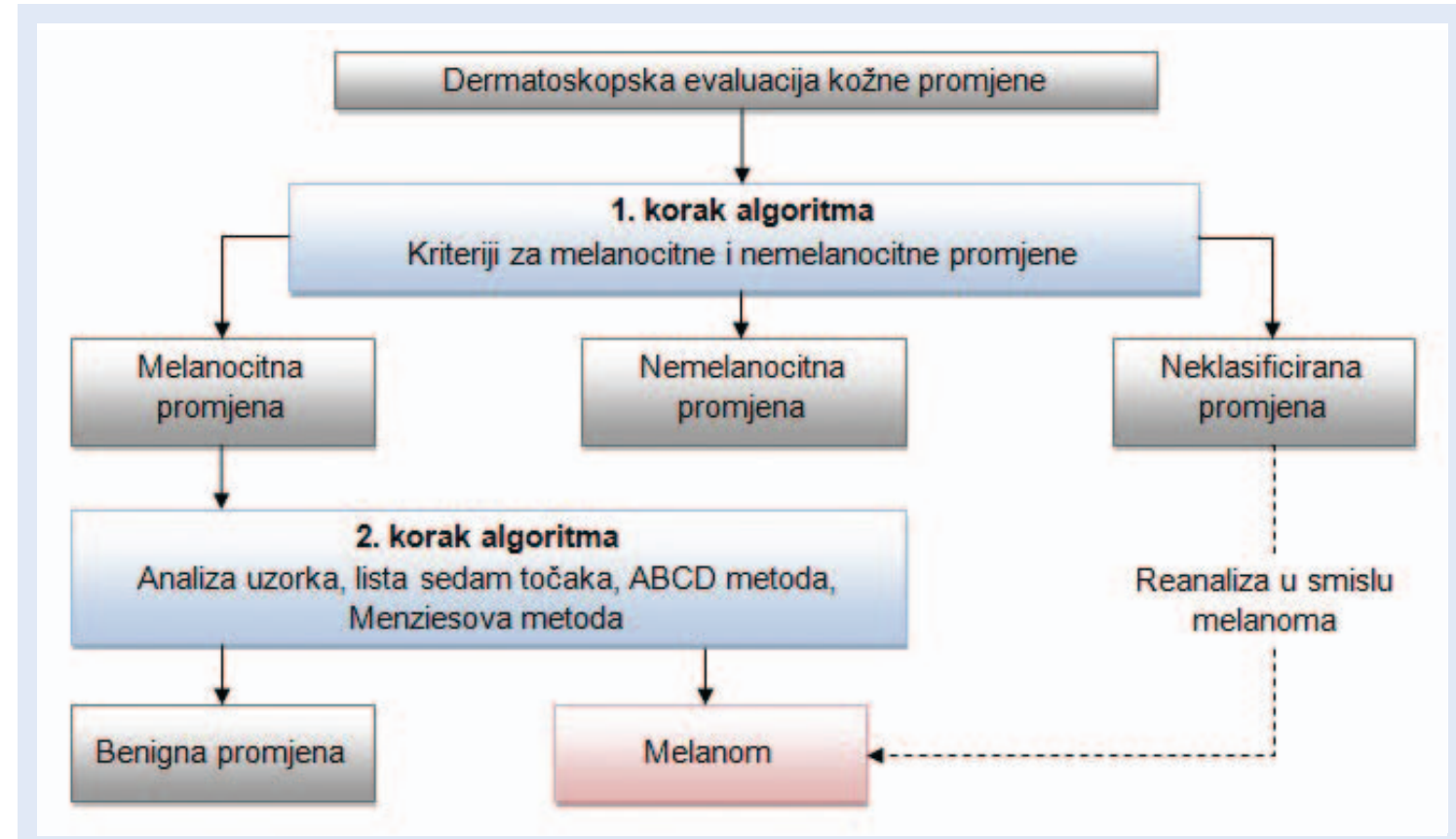

Slika 1. Shematski prikaz algoritma u dva koraka za razlikovanje melanocitnih od nemelanocitnih promjena kože te benignih melanocitnih promjena od melanoma 
gresijske strukture ${ }^{3}$. Svaki od prva tri navedena kriterija, koji se ujedno nazivaju i glavni ili specifični kriteriji, boduje se s dva boda, a jedan bod se daje svakom od posljednja četiri kriterija, koji se nazivaju dodatni kriteriji. Promjena koja ukupno ima 3 ili više boda smatra se dovoljno sumnjivom i ekscizija takve promjene je opravdana. Također se koriste i složenije metode dermatoskopije, kao što su analiza uzorka, ABCD metoda te Menziesova metoda ${ }^{3-6}$.

S obzirom na to da su mnoge dermatoskopske strukture u korelaciji s temeljnim patohistološkim promjenama, dermatoskopija se smatra mostom između kliničke i patohistološke dijagnostike ${ }^{3}$. Svrha ovog preglednog članka je na temelju dostupne literature prikazati kliničke tipove melanoma te načine njegova otkrivanja dermatoskopskim pregledom. Poseban značaj treba dati ranom otkrivanju melanoma na temelju njegove kliničke prezentacije i dermatoskopskih obilježja, budući da je rano otkrivanje melanoma presudno za preživljavanje i povoljan daljnji ishod bolesti.

\section{LENTIGO MALIGNI MELANOM}

Lentigo maligni melanom (engl. lentigo maligna melanoma) je oblik melanoma zastupljen u 5 $15 \%$ svih slučajeva melanoma. Javlja se najčešće u osoba starije životne dobi, podjednako u žena i muškaraca. Razvija se na koži oštećenoj sunčevim zračenjem, iz prekanceroze lentigo maligna, koja predstavlja lentigo maligni melanom in situ. Evolucija u invazivni oblik može trajati godinama ili čak nekoliko desetljeća, jer je za njegov razvoj ključan kumulativan učinak ultraljubičastog zračenja. U žena su česte lokalizacije obrazi, a u muškaraca nos i uške, jer su to mjesta kronično izložena suncu. U 10 \% slučajeva javlja se na ostalim eksponiranim područjima tijela, kao što su ruke i noge ${ }^{1,7,8}$.

Klinički, lentigo maligna obično se razvija kao spororastuća, asimetrična, svjetlosmeđa do crna makula s varijacijom boja i nepravilnim rubovi$\mathrm{ma}^{9}$. Maligni melanociti nalaze se u bazalnom sloju epidermisa i šire se prema površini i lateralno. To je horizontalna faza rasta ovog tumora. Budući da obično nastaje na koži ozbiljno oštećenoj suncem, teško se histološki razlikuje lentigo maligna od atipične melanocitne hiperplazije ${ }^{10,11}$. Pri- jelaz iz lentigo maligna u lentigo maligni melanom pojavljuje se u 5 - 50 \% slučajeva i karakteriziran je pojavom tamnih infiltriranih promjena, papula ili čvorića unutar postojeće lezije (vertikalna faza rasta) (slika $2 a)^{7}$.

Dermatoskopija melanoma na koži lica otežana je zbog specifičnosti građe kože lica s ravnom epidermodermalnom granicom, tankim epidermisom i velikim brojem pilosebacealnih jedinica. Asimetrično pigmentirani otvori folikula, koji se dermatoskopski vide kao sivi krugovi te sive točke, i globula u tim otvorima, odnosno krugovi u krugu, predstavljaju početne dermatoskopske kriterije za ranu dijagnozu lentigo malignog melanoma. Te strukture se kasnije razvijaju u anularni-granularni uzorak (engl. annular-granular pattern), koji odgovara finim sivim točkama, globulima i prugama oko i između otvora folikula (slika $2 b)^{2,3}$. Dermatoskopskim pregledom lentigo malignog melanoma uočavamo i pigmentirane romboidne strukture (engl.
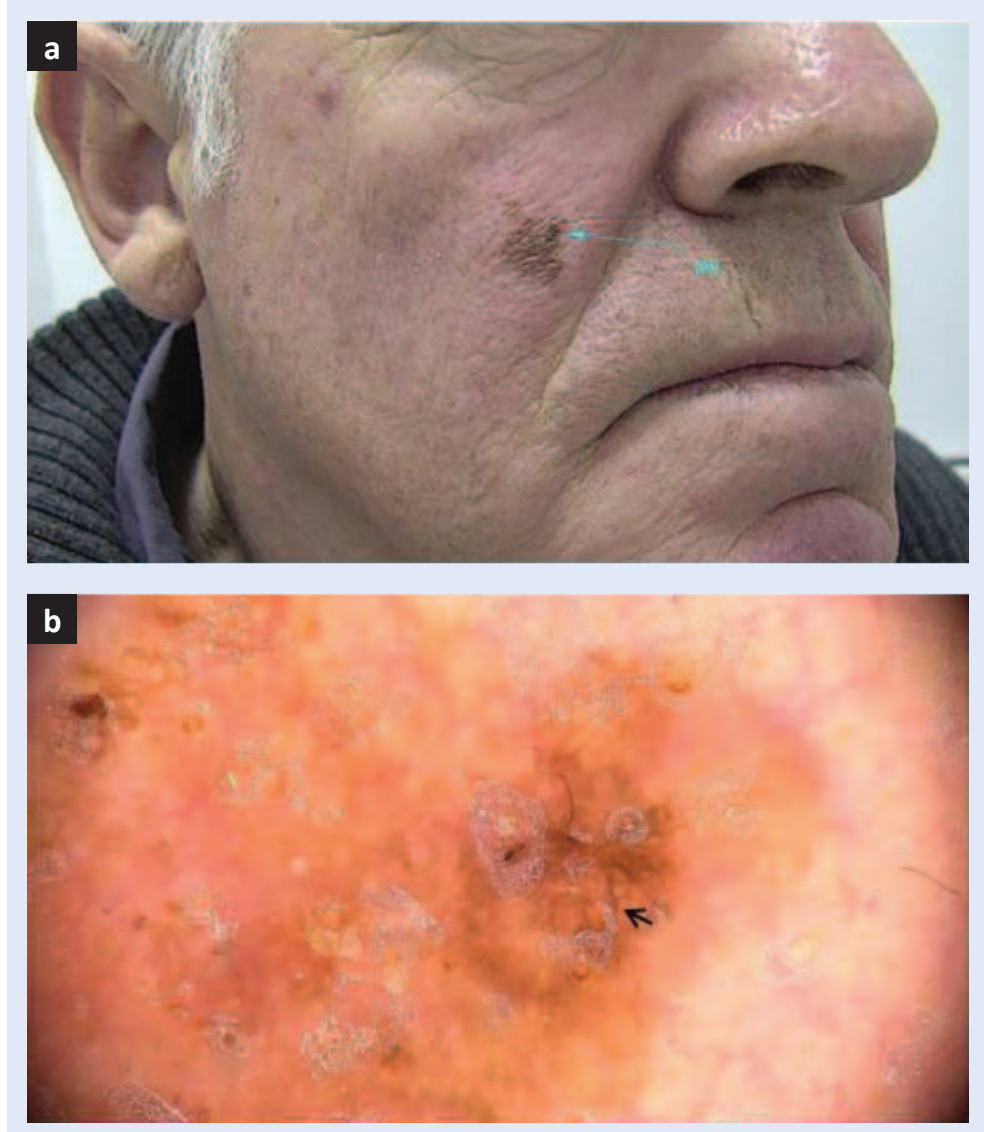

Slika 2. Klinička i dermatoskopska obilježja lentigo malignog melanoma Klinička obilježja lentigo malignog melanoma u smislu nepravilno pigmentirane smeđe do crne makulozne promjene (a) te dermatoskopska obilježja u smislu sivih granula i pruga između otvora folikula (crna strjelica) (b). 
pigmented rhomboidal structures) formirane od kratkih poligonalnih pruga te tamnosmeđe do crne mrlje (engl. blotches) s ili bez obliteriranih otvora folikula ${ }^{12}$. Novi dermatoskopski kriteriji za ovaj tip melanoma su zatamnjenje (engl. darkening) prilikom dermatoskopskog pregleda, odnosno prisutnost boje na dermatoskopskim slikama tamnije od svih klinički vidljivih nijansi smeđe ili sive. Također je novi kriterij i crvena romboidna struktura (engl. red rhomboidal structure), odnosno vaskularni uzorak oblika romba koji se pojavljuje na području koje odvaja folikule dlaka te povećana gustoća vaskularne mreže unutar lezije u odnosu na perifernu kožu ${ }^{13}$.

\section{POVRŠINSKO ŠIREĆI MELANOM}

Površinsko šireći melanom (engl. superficial spreading melanoma) čini oko $70 \%$ svih melanoma te je predominantni oblik melanoma u bijelaca. Javlja se češće u žena, u dobi od 40. do 50. godine života. $U$ muškaraca je lokaliziran obično na leđima, a u žena na donjim udovima ${ }^{9,14}$.

Ovaj oblik melanoma karakterizira spora horizontalna (radijalna) faza rasta u kojoj se maligni melanociti šire po epidermisu i papilarnom dermisu lateralno od središta lezije. Stoga on mijenja oblik radijalnim širenjem i regresijom. Nasumična migracija stanica, uz proces regresije, rezultira lezijama s beskrajnom raznolikosti oblika i veličina. Ova faza može potrajati od nekoliko mjeseci do nekoliko godina, nakon čega slijedi vertikalna faza rasta u kojoj maligni melanociti rastu prema površini epidermisa i u dublji dermis ${ }^{11,14}$.

$U$ horizontalnoj fazi rasta površinsko šireći melanom izgleda poput smeđe-crne makule ili blago uzdignutog plaka promjera do $1 \mathrm{~cm}$, nepravilnih, nazubljenih rubova i nejednolične pigmentacije ${ }^{11}$. $U$ vertikalnoj fazi rasta se izdiže iznad razine kože u obliku papule ili čvora, neravne bradavičaste površine, asimetričan, često ulceriran i promjera obično većeg od $1 \mathrm{~cm}$ (slika 3a) $)^{1,7,11}$.

Dermatoskopijom površinsko širećeg melanoma uočavamo atipičnu pigmentnu mrežu (engl. atypical pigment network), odnosno razlike u širini, boji i distribuciji linija pigmentne mreže (slika 3b). Područja između linija mreže nejednolika su veličinom i završavaju naglo na periferiji. Znak melanoma je i negativna pigmentna mreža (engl. negative pigment network), a prepoznajemo je prema vijugavim međusobno povezanim hipopigmentiranim linijama koje okružuju pigmentirane strukture. Može biti smještena difuzno ili fokalno unutar lezije ${ }^{15}$.

Na melanom također upućuju i nepravilni, asimetrični i fokalno smješteni radijalni tračci (engl. streaks) na periferiji lezije. Ako imaju proširenje na vrhovima nazivaju se pseudopodiji (engl. pseudopods) $)^{15}$.

Obilježje ovoga tipa melanoma su i točke i globuli. Točke (engl. dots) su male, okrugle, crne, smeđe ili plavo-sive strukture koje variraju u veličini, boji i distribuciji i nisu povezane s pigmentnom mrežom. Globuli (engl. globules) su okrugle do ovalne strukture smeđe, crne ili plave boje, veće od točaka te asimetrično distribuirane unutar lezije (slika 3b) ${ }^{15}$.
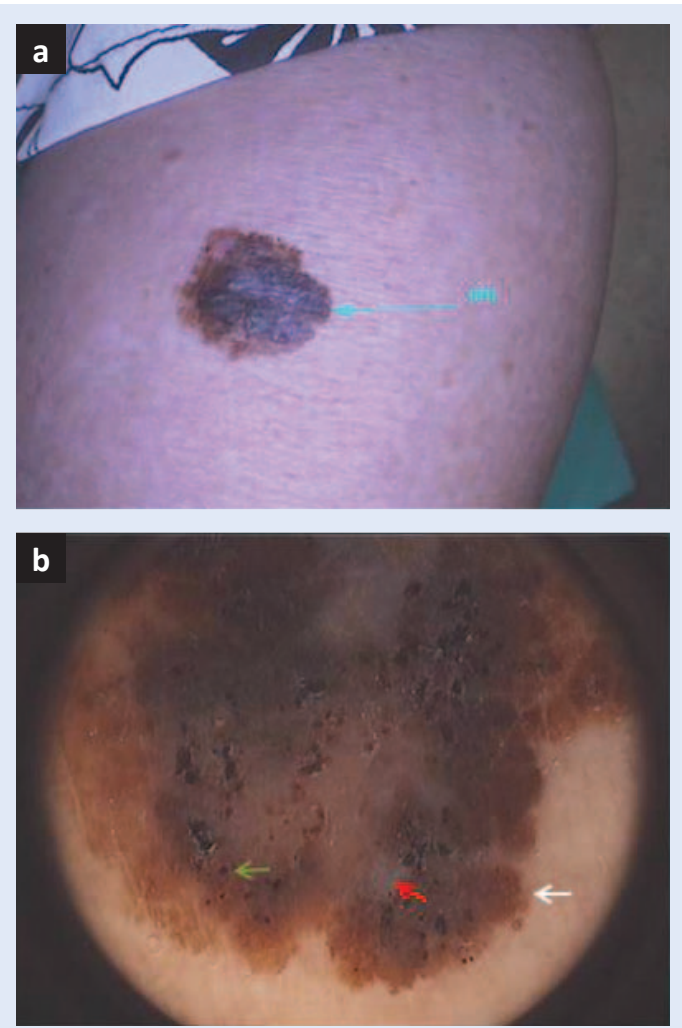

Slika 3. Klinička i dermatoskopska obilježja površinsko širećeg melanoma

Kliničko obilježje površinsko širećeg melanoma poput smeđe do crne izrasline nepravilnih, policikličkih rubova (a) te dermatoskopsko obilježje atipična pigmentna mreža (bijela strjelica), asimetrični smeđi globuli (zelena strjelica) i plavo-bijeli veo (crvena strjelica) (b) 
Dermatoskopske značajke melanoma su i regresijske strukture (engl. regression structures). Obično se prezentiraju kao područja bijele boje slična ožiljku (engl. scarlike areas) ili kao plavo-bijeli veo (engl. blue-white veil), odnosno konfluirajuća plava pigmentacija zamagljena slojem bijele boje poput stakla (slika $3 \mathrm{~b}$ ). U zonama regresije često se uočavaju i plavo-siva zrnata područja (engl. peppering) (slika 3b). Regresijske strukture kod melanoma obično su asimetrično smještene i često uključuju više od 50 \% lezije. lako ih možemo naći kod uznapredovalog površinsko širećeg melanoma, češće se javljaju kod nodularnog melanoma te kod akrolentiginoznog melanoma ${ }^{15-17}$.

Pri dermatoskopskom pregledu melanoma važno je uočiti i atipični vaskularni uzorak (engl. atypical vascular pattern). Dvije ili više različitih morfologija krvnih žila unutar iste lezije, odnosno polimorfni vaskularni uzorak (engl. polymorphous vascular pattern), znak je melanoma, kao i točkaste (engl. dotted vessels) i linearne nepravilne krvne žile (engl. linear irregular vessels) te mliječno crvena područja (engl. milky-red areas). Svjetlosmeđa područja bez strukture pigmenta (engl. structureless areas) lokalizirana na periferiji lezije i veća od $10 \%$ površine lezije upućuju na melanom. Ove su strukture obilježja kako uznapredovalog površinsko širećeg melanoma tako i nodularnog i uznapredovalog akrolentiginoznog melanoma ${ }^{15-17}$.

\section{NODULARNI MELANOM}

Nodularni melanom (engl. nodular melanoma) je brzo napredujuća neoplazma koja čini oko 15 $30 \%$ svih melanoma te je po učestalosti drugi po redu oblik melanoma ${ }^{3}$. Javlja se češće u muškaraca, najčešće u 5. i 6. desetljeću života. Trup je najčešća lokalizacija, a često se javlja i na glavi i vratu. Nastaje na prethodno nepromijenjenoj koži de novo ili iz pigmentnog nevusa ${ }^{1,14}$. Ima vrlo agresivno biološko ponašanje i visok metastatski potencijal, čak i u svojim ranim fazama. Kod ovog tipa melanoma, vertikalna faza rasta javlja se rano, nakon vrlo kratke horizontalne faza rasta koja može i izostati, stoga je u vrijeme dijagnoze ove vrste melanoma često već prisutan duboki i ulcerirani tumor. Prognoza nodularnog melanoma je loša, zbog njegovog vrlo brzog i agresivnog rasta u dubinu ${ }^{3}$.
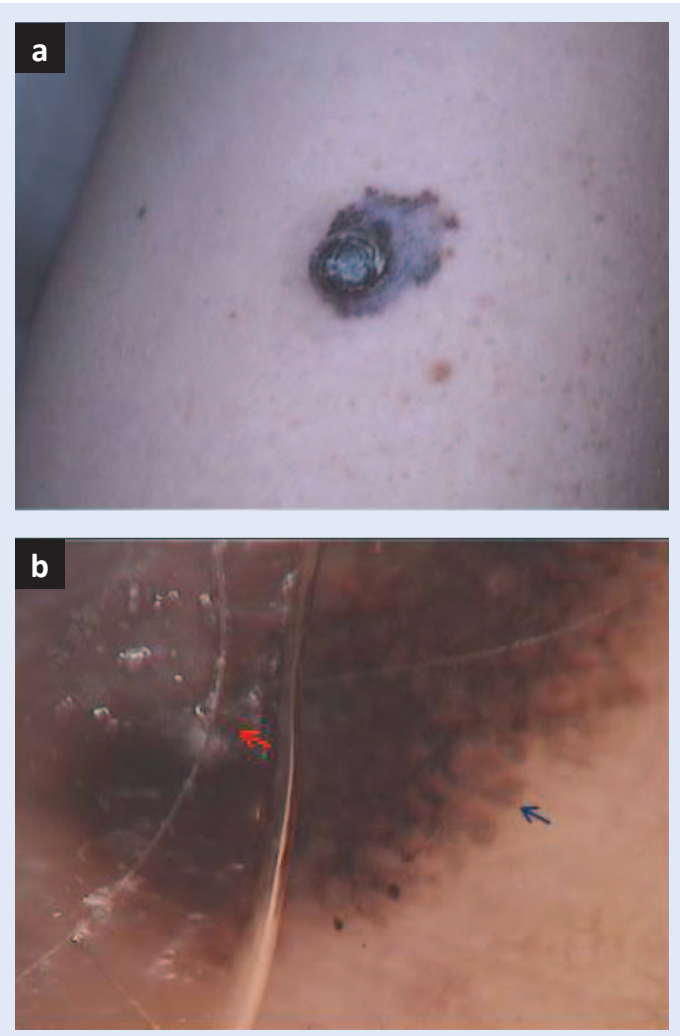

Slika 4. Klinička i dermatoskopska obilježja nodularnog melanoma

Kliničko obilježje nodularnog melanoma, odnosno crna, okrugla, homogena izraslina (a) te dermatoskopsko obilježje plavo-bijeli veo (crvena strjelica) i pseudopodiji (plava strjelica) (b)

Klinički, nodularni melanom je najčešće tamnosmeđe, crvenosmeđe ili crvenocrne boje, u obliku dobro ograničenog polipa ili čvora. Obično je tamniji od površinsko širećeg melanoma i većinom jednolike pigmentacije (slika 4a). Često je ulceriran i može krvariti ${ }^{7,14,11}$.

Budući da je nodularni melanom klinički obično jednolike pigmentacije, okrugao i simetričan, dermatoskopski rjeđe nalazimo atipičnu pigmentnu mrežu, atipične globule i točke te područja regresije, što je više zastupljeno kod površinsko širećeg melanoma. Međutim, prisutne su homogena plava pigmentacija, područja crne pigmentacije, plavo-bijeli veo i atipične krvne žile (slika 4b). Posljednjih godina Argenziano i suradnici uveli su izraz „plavo-crno pravilo“ (engl. blue-back rule), prema kojem istodobna prisutnost plavih i crnih područja, koja zauzimaju najmanje $10 \%$ površine lezije, značajno ukazuje na vjerojatnost pigmentiranog nodularnog melanoma ${ }^{3}$. 


\section{AKROLENTIGINOZNI MELANOM}

Akrolentiginozni melanom (engl. melanoma acrolentiginosum) čini oko $5 \%$ svih tipova melanoma u ljudi bijele rase, ali je najčešći tip u Afrikanaca, Azijata i Hispanaca (30 - 75 \%). Najčešće se javlja u dobi između 60. i 70. godine života, češće u muškaraca. Glavna karakteristika akrolentiginoznog melanoma je njegova pojava na neobraslim dijelovima tijela, tj. u predjelu dlanova i tabana te na noktima. Razvoj ovog tipa melanoma traje od nekoliko mjeseci do nekoliko godina ${ }^{1,18,19}$.

Subungvalni tip akrolentiginoznog melanomoma javlja se ispod nokta, najčešće na palcu stopala, gdje nastaje iz matriksa, hiponihija ili paronihija nokta. Klinički se u početku prezentira kao uzdužna smeđa ili crna nepravilna traka na nokatnoj ploči. Pojava pigmentacije na okolnoj koži, odnosno Hutchinsonov znak, klinički potvrđuje akro-
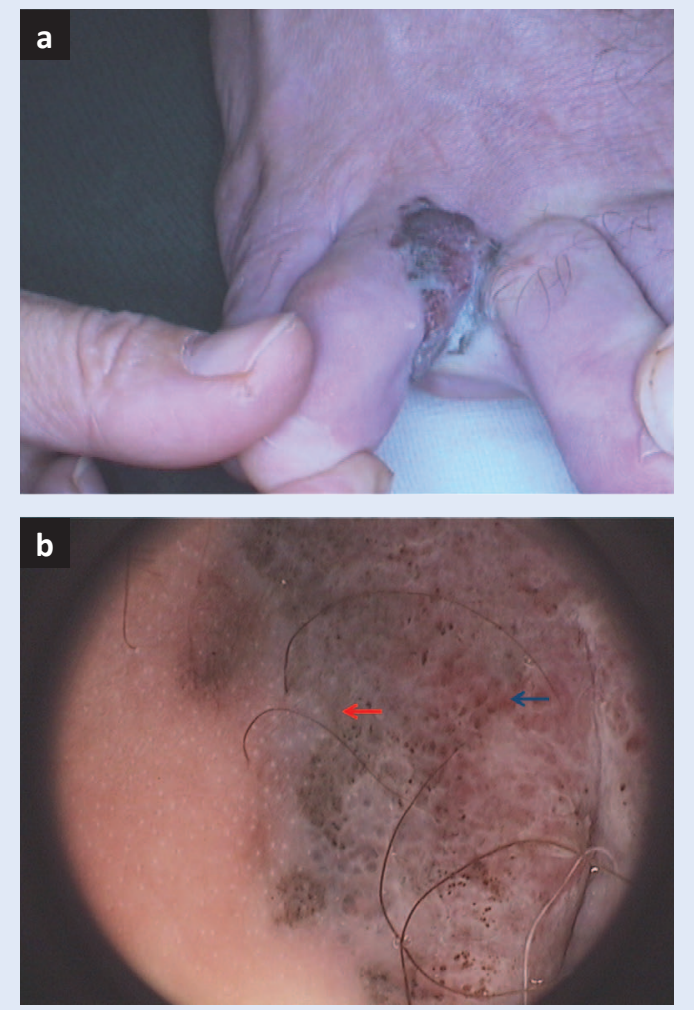

Slika 5. Klinička i dermatoskopska obilježja akrolentiginoznog melanoma

Kliničko obilježje akrolentiginoznog melanoma u smislu nejednoliko ružičasto do sivo pigmentirane, erodirane izrasline (a) te dermatoskopsko obilježje plavo-bijeli veo (crvena strjelica) i mliječno-bijele strukture (plava strjelica) (b) lentiginozni melanom gotovo u $100 \%$ slučajeva. Kasnije se javljaju krvarenje i ulceracija, a u uznapredovanom stadiju prst je otečen i uvećan, što se naziva melanomska paronihija ${ }^{7,20}$. Ako se pojavi izvan nokatne ploče, na koži dlanova i tabana, akrolentiginozni melanom je nejednoliko pigmentirana smeđa do crna makula, nepravilnih rubova. Nakon horizontalne faze rasta prelazi u vertikalnu i lezija postaje nodularna, nekad i ulcerirana (slika 5a) ${ }^{9}$. Akrolentiginozni tip melanoma je vrlo agresivan i rano metastazira. Najčešće se dijagnosticira u uznapredovalom stadiju i ima lošu prognozu ${ }^{7,20}$.

Benigna pigmentna lezija nokatne ploče dermatoskopski se prepoznaje po tankim, pravilnim i simetričnim pigmentnim prugama, za razliku od maligne lezije gdje su pruge asimetrično proširene i nepravilne, te šire u proksimalnom dijelu nokta za razliku od distalnog. Nekada možemo uočiti i pigmentaciju području kutikule koja se, ako je vidljiva samo dermatoskopom, naziva mikroHutchinsonov znak ${ }^{15,21}$.

Dermatoskopijom benignih pigmentnih lezija na dlanovima i tabanima uočavamo pigmentirane linije u području brazdi, tzv. paralelni uzorak brazdi (engl. parallel furrow pattern), dok je kod akralnog melanoma pigmentacija smještena u području grebena, tj. paralelni uzorak grebena (engl. parallel ridge pattern), a brazde su relativno hipopigmentirane. Napredni akrolentiginozni melanom gubi svaki odnos s brazdama i grebenima i pokazuje difuznu pigmentaciju, s crnosmeđim mrljama zbog difuzne i neuredne raspodjele melanocita u epidermisu i dermisu (slika 5b) ${ }^{2,3}$.

Dermatoskopska obilježja akrolentiginoznog melanoma su i multikomponentni uzorak (engl. multicomponent pattern), odnosno kombinacija više pigmentnih obrazaca, atipični fibrilarni uzorak (engl. atypical fibrillar pattern) i mliječno crvena područja uglavnom vidljiva kod debljih tumora kada postoji nodularna komponenta koja je vaskularizirana 22,23 .

\section{AMELANOTIČNI MELANOM}

Amelanotični melanom (engl. amelanotic melano$m a)$ rjeđi je oblik melanoma karakteriziran izostankom pigmentacije. S obzirom na količinu pigmenta može se podijeliti na potpuno amelanotični mela- 

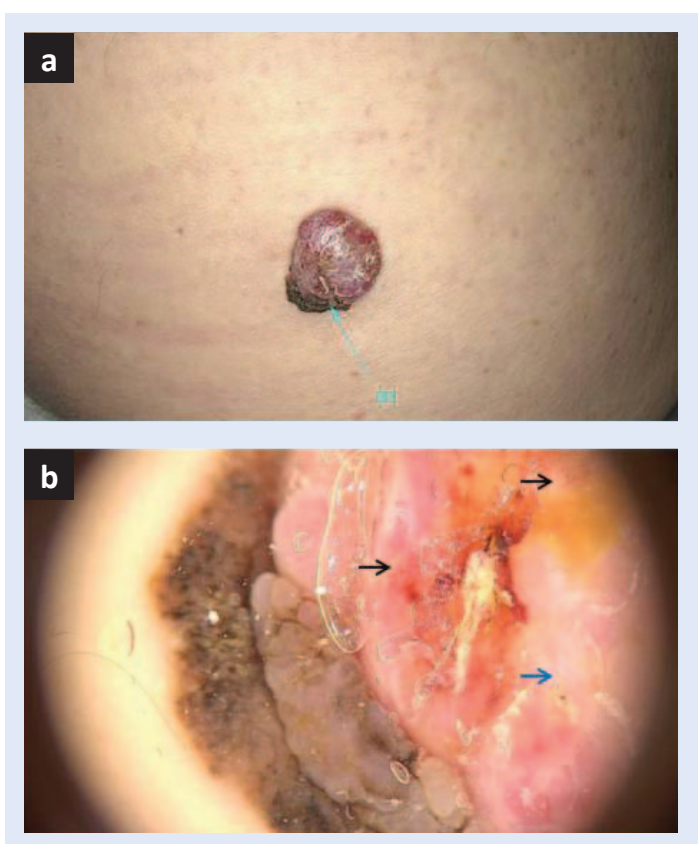

Slika 6. Klinička i dermatoskopska obilježja amelanotičnog melanoma

Kliničko obilježje amelanotičnog melanoma poput ružičaste izrasline uz melanocitni madež (a) te dermatoskopsko obilježje mliječno-bijele strukture (plava strjelica) i atipična vaskularizacija (crne strjelice) (b)

nom, parcijalno hipomelanotični ili parcijalno amelanotični melanom s cirkumskriptnom hipopigmentacijom i na slabo pigmentirane melanome $\mathrm{s}$ difuznom hipopigmentacijom ${ }^{24}$. Obično se javlja kao ružičasta papula, plak ili simetričan nodul, ponekad erodiran ili ulceriran. S obzirom na nedostatak pigmenta, teško se dijagnosticira (slika 6a). Patohistološki gledano, svi tipovi melanoma mogu se klinički prezentirati kao amelanotični melanom, ali najčešće su to dezmoplastični tip melanoma (više od $50 \%$ ), subungvalni tip melanoma (25\%), kutane metastaze melanoma i nodularni melanom? ${ }^{7}$.

Dermatoskopska dijagnoza amelanotičnog melanoma temelji se na prisutnosti atipičnog polimorfnog vaskularnog uzorka te mliječno crvenih homogenih područja ${ }^{3}$. Prema Menziesu i suradnicima linearne iregularne krvne žile (engl. linear irregular vessels) su predominatni tip, a u mnogim istraživanjima navode se i točkaste krvne žile (engl. dotted vessels), krvne žile oblika ukosnice (engl. hairpin vessels), vijugave krvne žile (engl. serpentine vessels), krvne žile poput glomerularnih (engl. glomerular vessels) te njihove kombi- nacije (engl. polymorphic vessels) (slika 6b) ${ }^{25}$. Kod amelanotičnih melanoma debljine manje od 0,5 mm obično su prisutne točkaste krvne žile distribuirane jednoliko unutar lezije, melanomi debljine 0,5-2 mm imaju i krvne žile oblika ukosnice, također $u$ jednoličnoj distribuciji, dok oni debljine veće od $2 \mathrm{~mm}$ imaju veće linearne iregularne i polimorfne krvne žile u asimetričnoj distribuciji. Periferno ili predominatno centralno smještene krvne žile također ukazuju na melanom. Važne dermatoskopske značajke amelanotičnog mela-

Dermatoskopski kriteriji specifični za melanom su atipična pigmentna mreža, plavo-bijeli veo, atipični vaskularni uzorak, atipične točke i globuli, nepravilni tračci, asimetrična pigmentacija i regresijske strukture. S obzirom na to da je melanom jedan od najagresivnijih tumora uopće, rana dijagnoza je temeljni cilj i preduvjet uspješnog liječenja.

noma su i više nijansi ružičaste boje, retikularna depigmentacija, bijela područja bez strukture, depigmentacija poput ožiljka, plavo-bijeli veo, brojne plavo-sive točke, bijele linije te ulceracija koja je češće vidljiva kod debljih lezija. Ako je u amelanotičnom melanomu dijelom prisutan pigment, dermatoskopski se vide nepravilno raspoređeni ostaci pigmentne mreže, atipične točke i globuli (slika 6b) 24,26 .

Dermatoskopijom amelanotičnog nodularnog melanoma uočavamo difuznu homogenu neorganiziranu pigmentaciju, s različitim nijansama asimetrično raspoređene ružičaste boje pomiješane $s$ atipičnim polimorfnim vaskularnim uzorkom, uključujući točkaste i linearne iregularne krvne žile, mliječno crvena područja te hipopigmentirane pseudolakune koje su nepravilne u veličini, obliku i distribuciji ${ }^{27}$.

\section{ZAKLJUČAK}

Incidencija melanoma u stalnom je porastu, a s obzirom na to da je melanom jedan od najagresivnijih tumora uopće, izrazito je važno prepoznati ga u ranom stadiju. Razvojem dermatoskopije, koja povezuje kliničku sliku i patohistologiju, došlo je do velikog napretka u dijagnostici melanoma. Dermatoskopija nam daje mogućnost da 
vizualiziramo specifične morfološke strukture koje nisu vidljive golim okom te tako omogućuje raniju detekciju melanoma u usporedbi s kliničkim pregledima bez dermatoskopije. Unatoč velikom napretku medicine, nije se znatno promijenilo preživljenje pacijenata $s$ udaljenim metastazama melanoma, stoga je rana dijagnoza temeljni cilj i preduvjet uspješnog liječenja.

Izjava o sukobu interesa: Autori izjavljuju da ne postoji sukob interesa.

\section{LITERATURA}

1. Šitum M. Melanom. In: Basta-Juzbašić A et al. (ur). Dermatovenerologija. Zagreb: Medicinska naklada, 2014;687-703.

2. Poduje $S$, Šitum M, Buljan M. Dermatoskopija u dijagnostici melanoma. In: Šitum M et al. (ur). Melanom. Zagreb: Medicinska naklada, 2016;139-62.

3. Russo T, Piccolo V, Ferrara G, Agozzino M, Alfano R, Longo $\mathrm{C}$ et al. Dermoscopy pathology correlation in melanoma. J Dermatol 2017;44:507-14.

4. Paštar Z, Lipozenčić J. Dermoskopija. In: Lipozenčić J et al. Dermatovenerologija. 3. izd. Zagreb: Medicinska naklada, 2011;23-7.

5. Holmes GA, Vassantachart JM, Limone BA, Zumwalt M, Hirokane J, Jacob SE. Using Dermoscopy to Identify Melanoma and Improve Diagnostic Discrimination. Fed Pract 2018;35:S39-S45.

6. Argenziano $G$, Catricalà $C$, Ardigo $M$, Buccini $P$, De Simone $P$, Eibenschutz $L$ et al. Seven-point checklist revisited. Br J Dermatol 2011;164:785-90.

7. Šitum M, Dediol I, Buljan M. Klinička slika melanoma. In: Šitum $\mathrm{M}$ et al. (ur). Melanom. Zagreb: Medicinska naklada, 2016;39-47.

8. Vrdoljak E, Šamija M, Kusić Z, Petković M, Gugić D, Krajina Z. Klinička onkologija. Zagreb: Medicinska naklada, 2013;219-26.

9. Garbe C, Bauer J. Melanoma. In: Bolognia JL, Jorizzo JL, Schaffer JV. Dermatology. 3rd ed. Vol. 2. Elsevier Saunders, 2012;1885-910.

10. Tannous ZS, Lerner LH, Duncan LM, Mihm MC Jr, Flotte TJ. Progression to invasive melanoma from malignant melanoma in situ, lentigo maligna type. Hum Pathol 2000;31:705-8.

11. Jukić D, Križanac Š, Damjanov I. Bolesti kože. In: Damjanov I, Seiwerth S, Jukić S, Nola M. Patologija. 4. izd. Zagreb: Medicinska naklada, 2014;697-728.
12. Schiffner $R$, Schiffner-Rohe J, Vogt $T$, Landthaler $M$, Wlotzke $U$, Cognetta AB et al. Improvement of early recognition of lentigo maligna using dermatoscopy. J Am Acad Dermatol 2000;42:25-32.

13. Pralong $P$, Bathelier E, Dalle $S$, Poulalhon N, Debarbieux $S$, Thomas L. Dermoscopy of lentigo maligna melanoma: report of 125 cases. Br J Dermatol 2012;167:280-7.

14. Habif TP. Malignant melanoma. In: Habif TP. Clinical dermatology. 5th ed. Elsevier Inc, 2010;860-71.

15. Jaimes N, Marghoob AA. The morphologic universe of melanoma. Dermatol Clin 2013;31:599-613.

16. Marghoob AA, Cowell L, Kopf AW, Scope A. Observation of chrysalis structures with polarized dermoscopy. Arch Dermatol 2009;145:618.

17. Braun RP, Gaide O, Oliviero M, Kopf AW, French LE, Saurat $\mathrm{JH}$ et al. The significance of multiple blue-grey dots (granularity) for the dermoscopic diagnosis of melanoma. Br J Dermatol 2007;157:907-13.

18. Bradford PT, Goldstein AM, McMaster ML, Tucker MA. Acral lentiginous melanoma: incidence and survival patterns in the United States, 1986-2005. Arch Dermatol 2009;145:427-34.

19. González M, Tchernev G, Atanasova-Chokoeva A, França K, Lotti T. Multiple Primary Acral Lentiginous Melanomas (MPALM). Open Access Maced J Med Sci 2017;5:805-6.

20. Greenwald E, Anonymous Patient, Polsky D, Liebman TN. Acral Melanoma: A Patient's Experience and Physician's Commentary. Dermatol Ther (Heidelb) 2018;8:503-7.

21. Littleton TW, Murray PM, Baratz ME. Subungual Melanoma. Orthop Clin North Am 2019;50:357-66.

22. Braun RP, Thomas L, Dusza SW, Gaide O, Menzies S, Dalle $S$ et al. Dermoscopy of acral melanoma: a multicenter study on behalf of the International Society of Dermoscopy. Dermatology 2013;227:373-80.

23. Lallas A, Kyrgidis A, Koga H, Moscarella E, Tschandl P, Apalla $Z$ et al. The BRAAFF checklist: a new dermoscopic algorithm for diagnosing acral melanoma. Br J Dermatol 2015;173:1041-9.

24. Paštar Z, Lipozenčić J. Dermoscopy in Melanoma Prevention. Medicus 2007;16:59-67.

25. Stojkovic-Filipovic J, Kittler H. Dermatoscopy of amelanotic and hypomelanotic melanoma. J Dtsch Dermatol Ges 2014;12:467-72.

26. Menzies SW, Kreusch J, Byth K, Pizzichetta MA, Marghoob A, Braun R et al. Dermoscopic evaluation of amelanotic and hypomelanotic melanoma. Arch Dermatol 2008;144:1120-7.

27. Pizzichetta MA, Kittler H, Stanganelli I, Ghigliotti G, Corradin MT, Rubegni $P$ et al. Dermoscopic diagnosis of amelanotic/hypomelanotic melanoma. $\mathrm{Br} J$ Dermatol 2017;177:538-40. 